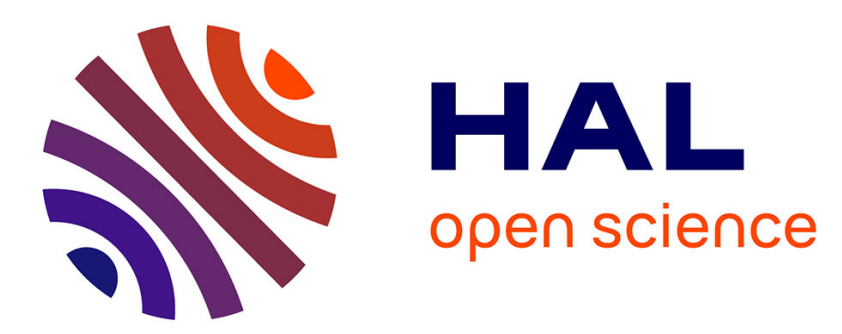

\title{
Deregulation and the crisis of dairy markets in Europe: facts for economic interpretation
}

\author{
Thierry Pouch, Aurélie Trouvé
}

\section{To cite this version:}

Thierry Pouch, Aurélie Trouvé. Deregulation and the crisis of dairy markets in Europe: facts for economic interpretation. Studies in Political Economy, 2018, 99 (2), pp.194-212. 10.1080/07078552.2018.1492216 . hal-02050761

HAL Id: hal-02050761

https://hal.univ-reims.fr/hal-02050761

Submitted on 5 Mar 2019

HAL is a multi-disciplinary open access archive for the deposit and dissemination of scientific research documents, whether they are published or not. The documents may come from teaching and research institutions in France or abroad, or from public or private research centers.
L'archive ouverte pluridisciplinaire $\mathbf{H A L}$, est destinée au dépôt et à la diffusion de documents scientifiques de niveau recherche, publiés ou non, émanant des établissements d'enseignement et de recherche français ou étrangers, des laboratoires publics ou privés. 


\section{Studies in Political Economy}

\section{Deregulation and the crisis of dairy markets in Europe: facts for economic interpretation}

\section{Thierry Pouch \& Aurélie Trouvé}

To cite this article: Thierry Pouch \& Aurélie Trouvé (2018): Deregulation and the crisis of dairy markets in Europe: facts for economic interpretation, Studies in Political Economy, DOI: 10.1080/07078552.2018.1492216

To link to this article: https://doi.org/10.1080/07078552.2018.1492216

曲 Published online: 29 Nov 2018.

Submit your article to this journal 전

Џlll Article views: 1

View Crossmark data \lceil 


\title{
Deregulation and the crisis of dairy markets in Europe: facts for economic interpretation
}

\author{
Thierry Pouch ${ }^{\mathrm{a}, \mathrm{b}}$ and Aurélie Trouvé \\ ${ }^{\mathrm{a}}$ French Agricultural Chambers, Paris, France; ${ }^{\mathrm{b}}$ Laboratoire Regards, Université de Reims Champagne \\ Ardenne, Reims, France; 'AgroParisTech, UFR d'agriculture compare, Paris, France
}

\begin{abstract}
The European Union is currently experiencing a structural crisis of overproduction in the dairy sector, following a rapid and farreaching deregulation of markets. No agricultural policy tool so far has been able to solve this crisis in a coordinated way on a European scale. This inability of European authorities is linked to the use of economic theories that deny the possibility of such a crisis.
\end{abstract}

\section{KEYWORDS}

Agricultural policy; dairy markets; deregulation; EU; European Union

\section{Introduction}

Within the framework of the Common Agricultural Policy (CAP), a range of instruments was established at the end of the 1960s in order to protect dairy producers from the volatility of international prices. They include guaranteed prices and public storage of both butter and powdered milk, and export subsidies as well as high and variable protection at the borders. These instruments gave rise to a substantial increase in production, beyond the absorption capacities of markets, and to a high increase in allocated financial backings. In response, the administrative control of production with milk quotas was established from 1984 onwards, and dairy markets became highly regulated by the CAP until the beginning of the 2000s.

As with cereals and beef in the 1990s, however, a dairy market liberalization process was set in motion by the European Union (EU) as early as 2004, with a progressive decrease in guaranteed prices, compensated with subsidies paid directly to the farmers. The abolition of milk quotas was confirmed in 2008 with what the European Commission called a soft-landing strategy, that is, the progressive increase in quotas by one percent per year from 2006/2007 to 2013/2014, until their final removal on March 31, 2015.

In this context of deregulation, domestic prices were brought into alignment with the international prices and became highly volatile. Prices decreased significantly in 2009 and from 2014 onwards, resulting in dairy farms undergoing increasing economic difficulties, including bankruptcies and farmers halting the production. ${ }^{1}$ It 
took a long time for the European Commission and its experts from the Agricultural Authority to accept the idea, and even longer to accept the reality of an economic crisis in the dairy sector, referring only to the vague notion of the market "imbalance."

In France, this deregulation of markets has led to a fundamental change in the balance of power between tens of thousands of European producers and a few dozen major processing companies, especially those that are not cooperatives, and large purchasing groups.

This article takes a necessary critical view of the economic phenomenon triggered by the end of the milk quota system. Why was the decision to abrogate this milk market regulation instrument made without anticipating the evolution of global supply and demand? Why did Europe, milk producers, and a large majority of economists underestimate the scale of the imbalance between European supply and the actual status of global demand? One did not need to be a milk-market expert to understand that once production is no longer quantitatively contained, producers will increase productive capacity and assume that the market will absorb the additional production.

First, this article reviews the definition of an agricultural crisis, in particular by distinguishing the economic and structural dimensions of a crisis. It then highlights the current structural milk overproduction crisis, highly predictable on the European scale. The third part shows how market deregulation eliminated all the efficient agricultural policy tools that could have resolved the crisis. The last section calls upon basic economic theories to help interpret the dairy crisis. ${ }^{2}$

\section{Typology of agricultural crises}

The notion and possibility of a crisis divides economists. Traditionally, it puts into opposition two groups of economists:

- Economists for whom a crisis cannot exist because market forces have balancing capacities, or who reckon that a crisis can occur only because of the exogenous factors that do not question the self-regulating nature of long-term markets. Nevertheless, such economists are not opposed to a certain regulation of milk markets, considering the specificities of the milk sector-daily milking, perishable product that is difficult to store, and so on; the price volatility that blocks any economic decision-making (notably regarding investment and job creation), and imperfect competition. ${ }^{3}$ Further, the empirical school of economics has developed instruments to define and measure a crisis, such as a succession of quarters of negative growth, instruments that economists could have used to convince themselves that a crisis was coming in the milk sector; and

- Economists who perceive crises as central to economic activity, as a feature that intervenes at regular intervals, potentially taking on a structural dimension. This is the case of the French regulation school in particular, ${ }^{4}$ which underlines deep imbalances, or even "major crises" potentially appearing in one or several economies and revealing the limits of capital accumulation systems and regulation methods. The transition from one system to another most often takes place through a crisis. 


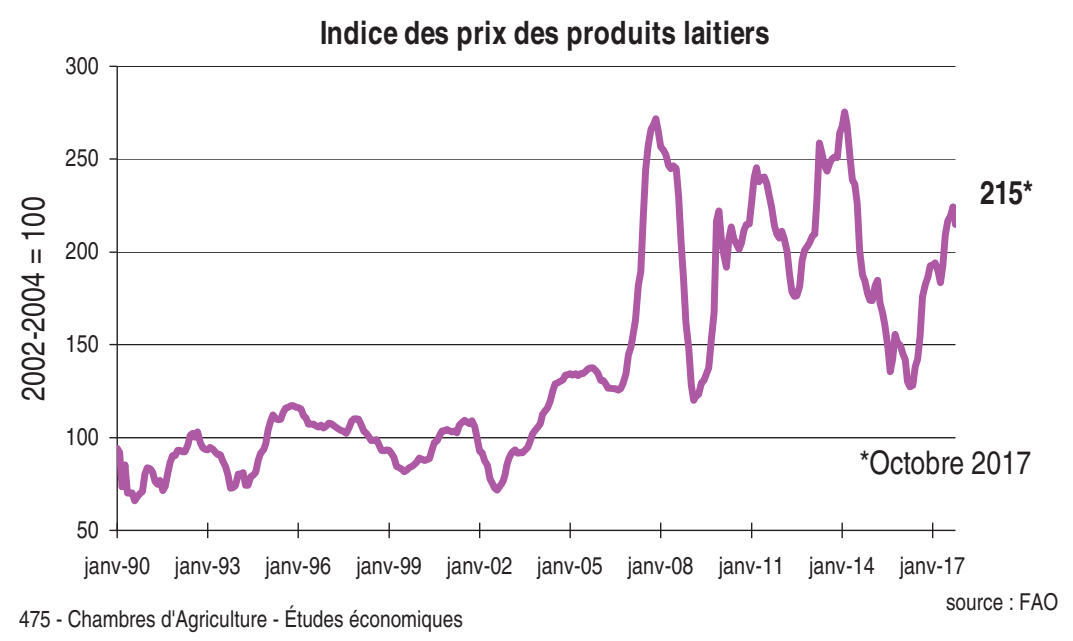

Figure 1. Evolution of the Dairy Product Price Index in the World.

Economic crises are generally apprehended on a national scale-as, for example, the French economic crisis marked by two or three consecutive quarters of negative growth-or on a global scale. In the latter case, an increase in the degree of interdependency of nations leads to mechanisms for spreading the crisis to all countries taking part in the globalization process, with the economic and financial crisis of 2007-2008 being a recent illustration of it. But what about a sector crisis? What triggers it and what are its repercussions? At which stage, or on the basis of which indicator, can we say that agriculture has or has not entered a critical phase? In what follows, we outline a typology of crises distinguishing economic from more structural crises.

At the level of a sector, the abolition of milk quotas illustrates the passage from an administered regulation established in 1984, to a competitive regulation set in motion in the 2000s. In this context, crises can happen. Knowing what kind of crises we are talking about is important in that crisis-exiting tools must be assessed according to their capacity to outline exiting strategies and solve the crisis concerned.

Since the middle of the 2000s, agricultural markets, including dairy markets, have been exposed to the increased volatility of prices (see Figure 1), which, because of certain characteristics peculiar to agricultural markets, have been undergoing a socalled "chaotic" evolution. 5 This price volatility had been specifically contained by appropriate regulation instruments, including guaranteed prices, which generally stabilized European prices and disconnected them from international prices (see Figure 2). Entering an era of chronic agricultural market instability had repercussions for farm income profiles, particularly those of dairy farms that have become particularly variable.

In this case, we distinguish between two types of crises: economic crises and structural crises (Table 1). In agricultural markets, an economic crisis involves a temporary imbalance between the supply and demand. The period from 2007 to 2009 is a good illustration of this, with price and income variations caused by several factors: 
Prix des produits laitiers en France jusqu'à fin avril 2017

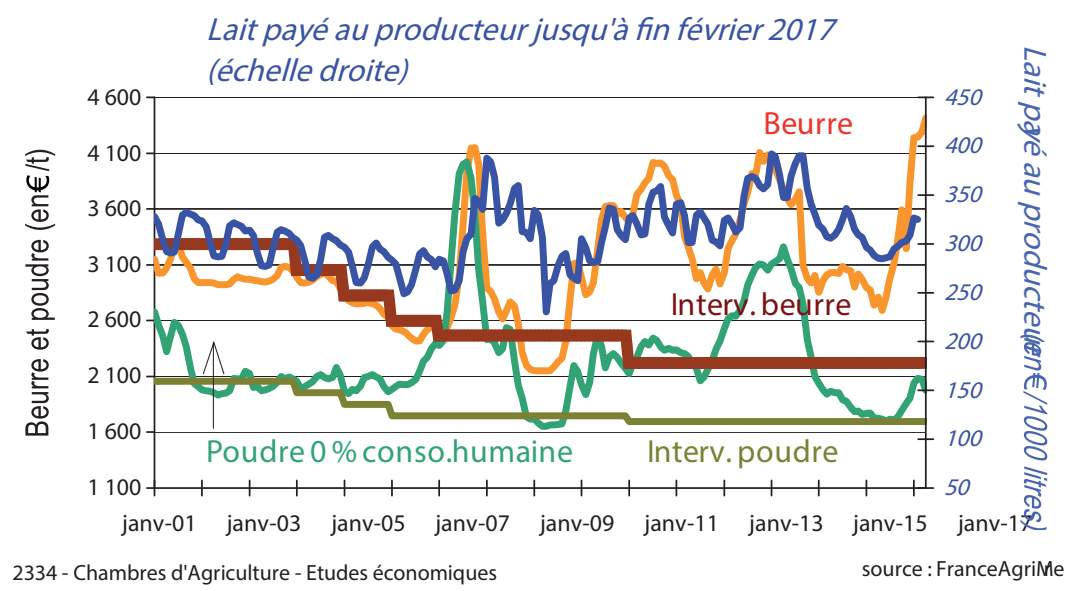

Figure 2. Evolution of Dairy Product Prices.

Table 1. Estimated Increase in the Milk Production of Main European Producers (2014-2024).

\begin{tabular}{lcc}
\hline Member States & Variation of production in \% & Variation in million tonnes \\
\hline Holland & 17.3 & 2.2 \\
Germany & 9.5 & 3.1 \\
Denmark & 8.0 & 0.4 \\
Poland & 14.7 & 1.8 \\
Belgium & 6.1 & 0.2 \\
Ireland & 27.2 & 1.7 \\
United Kingdom & 4.5 & 0.6 \\
France & 8.9 & 2.4 \\
Total & - & 12.4 \\
\hline
\end{tabular}

Source: Jongeneel and Van Berkum, 2015.

- Meteorological conditions, which can lead to a reduction or increase in supply. As such, the world market prices of dairy products experienced a remarkable explosion in 2007, linked to a one percent decrease in the production in the Oceania region, as a result of the drought. Likewise, EU producers had increased their production, and stocks of dairy products were far too low to supply the worldwide market;

- The macroeconomic climate, including a recession causing trade-offs in the house hold food expenditures. This was the case in 2008 and 2009, when global demand slowed following the economic and financial crisis. Due to the European decision to increase quotas by one percent, and already-increasing market prices, volumes were higher than the demand, which provoked a temporary collapse in prices. These were on the increase again from 2010, stimulated by an increase in global demand emanating from China, Russia, and Japan in particular;

- Erroneous price expectations, as illustrated by the Cobweb Theorem, which leads to short price cycles displaying relative regularity. Indeed, there is an important delay between the moment an individual producer decides to increase production and the moment production is actually made available on the market. ${ }^{6}$ As a result, 
the offer available at a given period is determined by the price of the previous period. High price at time $t-1$ will lead to an increase in the production and, eventually, to a price decrease at time $t$, consequently leading to a decrease in production and thus to an increase in price at time $t+1$. In 2007, the price paid to milk producers was relatively high, which stimulated production and led, in 2008, to overproduction and a drop in price in response.

Since 2014, however, the dairy industry can also be characterized by a higher degree of crisis. This time, a structural crisis is involved, which is characterized by:

- The fact that the crisis lasts more than a year;

- An accelerated rate of long-term income decreases that cannot be contained or reversed by market organizational rules; and

- The fact it is underpinned by a socially unacceptable dimension calling into question the foundations of the previously adopted productive paradigm, and the allocation of production factors between industry actors.

In fact, the internationalization and deregulation of the markets are factors that can trigger structural crises in the dairy sector. The milk quota system had been controlling competitiveness between European producers, with each country benefitting from an authorized and guaranteed volume. The decision to abolish milk quotas, in association with price deregulation, brought producers into a competitive process that could be amplified by an increase in the number of free trade agreements, reinforcing competition with third countries. Finally, with the dismantling of milk quotas, relations between actors became destabilized throughout the industry. ${ }^{7}$

The advent of a structural crisis in dairy markets that are being deregulated is favoured by two types of rigidity:

- Rigidity in the supply, which does not decrease or might even continue to increase in the case of a price drop. Indeed, producers face many fixed costs (linked in particular to investments in buildings, milking equipment, etc.), which do not vary in proportion to production. Faced with a drop in the sale price, this situation can bring them to produce more to cover these fixed costs, even if variable costs increase. This results in an increase in supply, leading producers to enter a phase of overproduction that will be all the more difficult because every one of them will adopt the same price compensation strategy by increasing volumes ${ }^{8}$; and

- Rigidity in demand, which is globally inflexible. Here, industrialized economies play a larger role than developing economies, where an increase in household incomes and a drop in prices have few repercussions for consumed volumes. This puts a lot of pressure on lowering prices and it threatens the economic efficiency of dairy farms, more so during overproduction periods.

A structural crisis can then lead to production growth stumbling in the long term because of a lack of markets. The increase in production costs, compared to insufficiently remunerative prices, is translated into a decrease in income for 
producers, with the risk of the concentration of supply accelerating and the most fragile livestock farmers being eliminated, with adverse effects on land usage and farm employment.

\section{The agricultural structural crisis in the European dairy sector}

We argued previously that the 2009 crisis fits into the category of economic crises. The crisis triggered in 2014, on the other hand, can be considered a structural crisis of overproduction.

The decision to abolish milk quotas came in a specific context. For several years already, the global demand for dairy products had experienced a rising trend that was set to continue over the coming decade, or even beyond. Successive agricultural forecasts carried out jointly by the Organisation for Economic Cooperation and Development (OECD) and the Food and Agriculture Organization (FAO) show that, under the combined effects of a number of factors-population growth, increases in the standard of living in emerging countries, urbanization, and the nutritional transition raising the issue of the more-or-less pronounced standardization of food consumption methods-the demand for dairy products should be experiencing regular growth by the 2020s, in the region of more than two percent per year. ${ }^{9}$ In the case of China, we know that health risks inherent to local production-which, in itself, is not high enough to meet the needs of a population increasingly consuming dairy products-compelled Beijing to progressively import more milk powder and vitamin-enriched milk. ${ }^{10}$ This would be enough to offer new outlets for the EU dairy industry because the intracommunity market had reached a certain maturity.

The decision to abolish milk quotas was manifestly an incentive for producers to grasp the opportunities offered by booming international markets since the beginning of the 2000s. Indeed, in December 2014, Phil Hogan, the new European Commissioner from Ireland, as well as his staff, indicated that the abolition of milk quotas was creating a lever to increase production and to supply international markets. As such, EU presence would be reinforced on these markets against competitors from New Zealand or even the United States.

However, the Commission made an important planning error. Since 2014, the main emerging countries have been in a pronounced economic slowdown and have not managed to offset the slack demand in the industrialized countries, creating the possibility of overproduction in the long term. ${ }^{11}$ For example, China's economic growth rate changed from almost 15 percent per year until the crisis of 2007, to less than seven percent in 2016, which is the lowest rate in 25 years. In 2015, China had a net drop in imports of dairy products. ${ }^{12}$ The relative withdrawal of China from world markets can be explained by the resumption of domestic production and the contraction of household consumption. In total, in 2014 we witnessed a three percent contraction of world trade according to World Trade Organization (WTO) data. The evolution of growth in Latin America and the North African and Middle East regions in $2015 / 2016$, and therefore of their domestic demands, is hardly more favourable. ${ }^{13}$ Consequently, the issue of international outlets is being raised in the case of the dairy sector. ${ }^{14}$ 


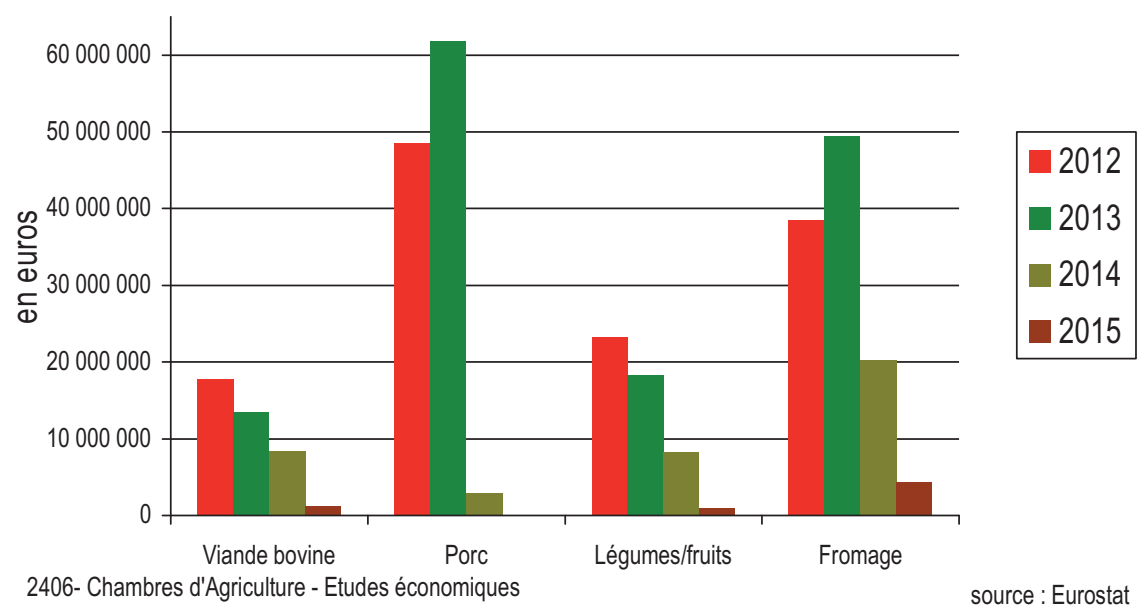

Figure 3. Evolution of French Exports of Food Products to Russia.

In terms of perspectives, two other important developments need to be considered. The first highlights the fact that, despite the 2007 crisis, the current cycle of global indebtedness is persisting, which means that economies again run the risk of undergoing an international economic and financial crisis, which would not be without consequences in terms of the dynamic of the demand for food products. ${ }^{15}$ The second concerns the slowdown of goods-trading since 2007, leading some economists to confirm their diagnosis of long-term growth stagnation. ${ }^{16}$

In addition to the uncertainty of global economic growth, there is also a link to geopolitics and its effects on market growth. Indeed, the Russian embargo, established in the summer of 2014, had significant consequences for European, and, more specifically, French exports of dairy products (Figure 3). In the case of Russia (Moscow being one of the main importers of cheese worldwide), even in the absence of the ban, two parameters can obstruct the capacity of this market to absorb European dairy productions in the long term. One parameter is the decrease in population growth $(-0.3 \%$ per year by 2024$)$ and the other is domestic production potentially building up again, thanks to the embargo. ${ }^{17}$

The main European countries producing and exporting dairy products were satisfied with the abolition of milk quotas and claimed to be ready to conquer world markets. We can say that some saw abolition as a relief, even, because it liberated production quota; this was the case for Ireland, which was strongly opposed to its establishment in 1984. Many member states (including Germany, Belgium, Denmark, Poland, Estonia, Ireland, Spain, Italy, Cyprus, Luxembourg, Holland, and Austria) had, in fact, exceeded their production quotas as early as 2014, thereby paying fines that, combined, came to 818 million Euros. Finally, milk production increased strongly in some of these countries, which contributed to the European overproduction (Figure 4).

According to the estimates carried out by the University of Wageningen, milk production could be increasing by five percent, to 30 percent by 2024 , depending on the European country concerned. Producers and processing firms have made 


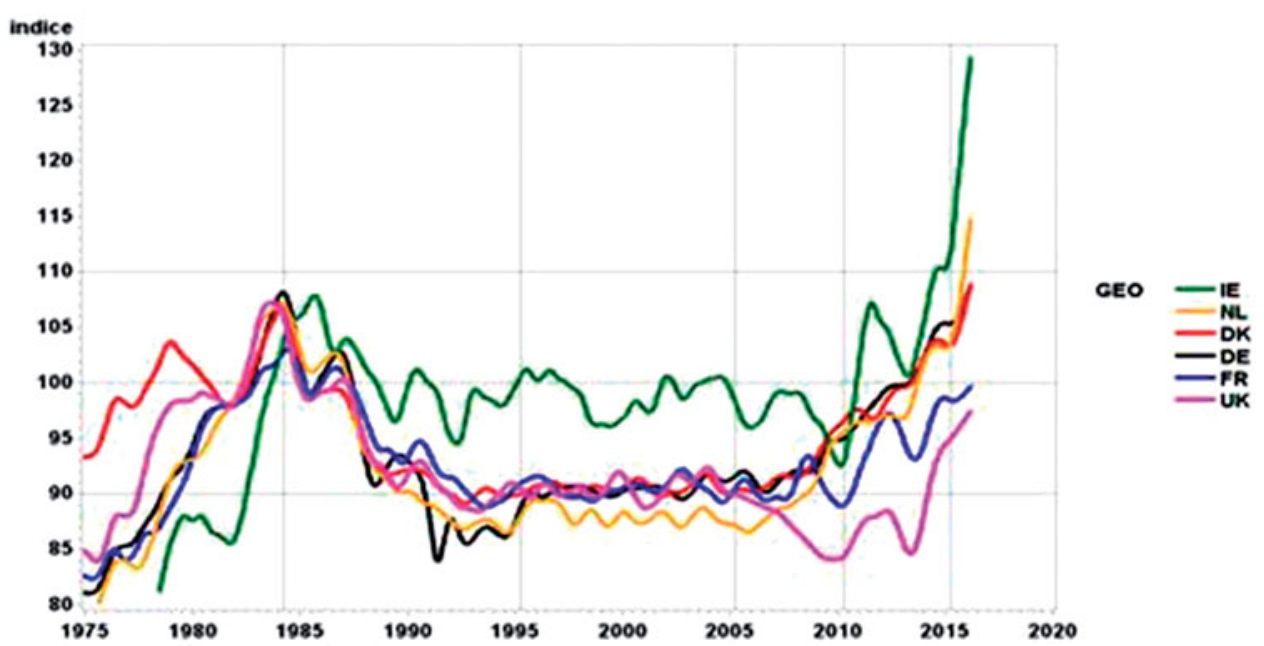

Figure 4. Cumulative Milk Collection Over 12 Months (Index 100 in 1984/1985).

Data from Eurostat, processed by "IDELE." IE: Ireland; NL: Netherlands; DK: Denmark; DE: Germany; FR: France; UK: United Kingdom

substantial new investments that now require a return. As our interviews in these countries indicate, the end of milk quotas served as an opportunity to again increase production in regions with already high dairy density, and therefore lesser pick-up costs and/or productive systems with lower production costs.

In the face of weakening exports to third countries-for example, the Russian embargo and decreasing Chinese imports-each of these countries is hoping to sell more products in the European space where prospects are stagnating; this can lead only to an even more obvious generalized overproduction. Furthermore, by expanding the search for exports to other third countries, the latter maintain exacerbated competition among themselves and with other major exporting countries outside the EU. The EU-28, and France in particular, have experienced this since the beginning of 2015. Indeed, New Zealand, as an important supplier of dairy products on the Chinese market, was affected badly by the interruption of Chinese growth. It then looked for markets open to imports, such as Algeria, with its sustained demand for dairy products. French farmers then encountered the dumping of tonnes of milk and dairy products from New Zealand.

Milk production increases in emerging economies can only amplify world overproduction, as shown in investments made or programmed in China's dairy sector. Milk production had already increased by close to 12 times between 1985 and 2011. In addition to national investments, multinationals (from Europe and New Zealand among others) are planning to make important investments in China, particularly in dairy plants with tens of thousands of cows.

Moreover, it is useful to highlight the EU's specific role in the overproduction crisis that has been undermining international dairy markets. The international milk market is, in fact, fairly restricted. Every year, around only seven to eight percent of milk production worldwide is the subject of commercial transactions in the form of exports. Three major producers share this export market: New Zealand (27 


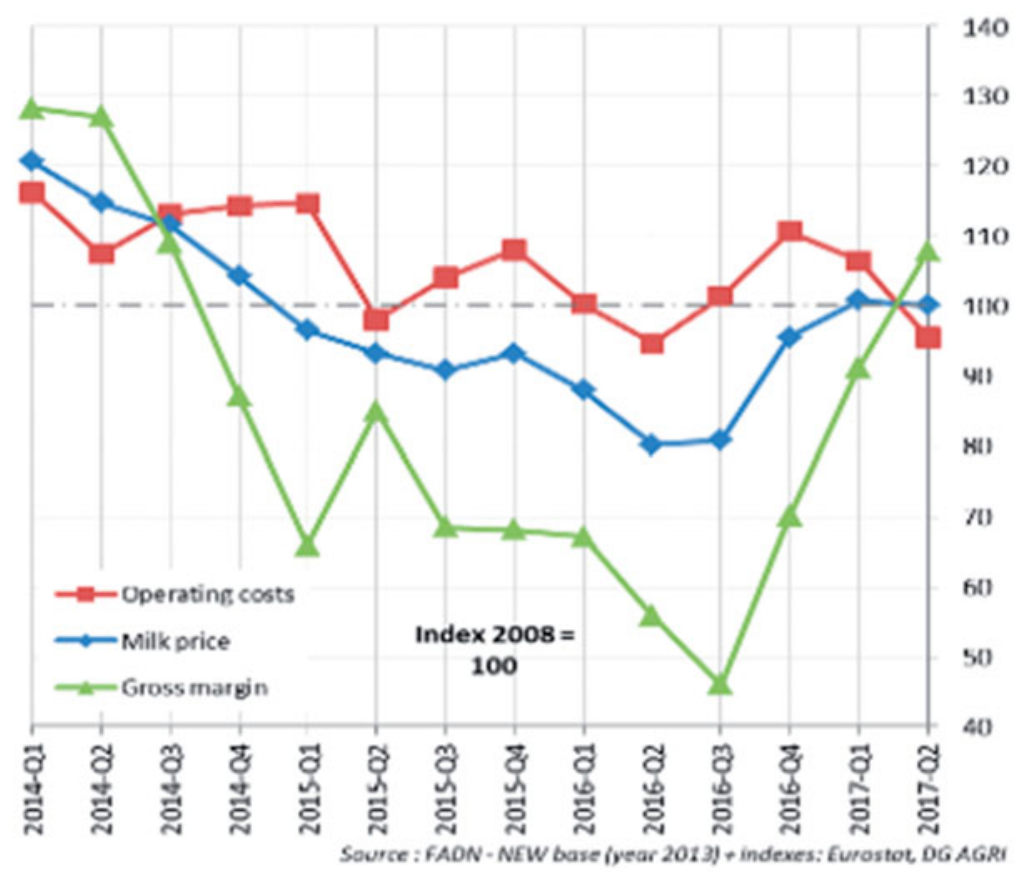

Figure 5. Estimation of EU Milk Price, Operating Costs, and Margin per Tonne.

percent), followed by the EU (23 percent), and the United States (15 percent). In 2014, New Zealand, the EU, and the United States increased their production respectively by nine percent, five percent, and $2.5 \%$ compared to 2013 , resulting in an exportable surplus of some 11 million tonnes on a 55 million ton export market. In 2015, the EU experienced a high increase in production $(+3.2$ million tonnes compared to production in 2014) against slack domestic consumption, ${ }^{18}$ while the United States increased production by just 1.2 million tonnes, and New Zealand actually decreased production by -0.3 million tonnes. ${ }^{19}$ From this, we can conclude that the EU, in 2015, became the main country responsible for oversupplying export markets.

Another factor of uncertainty for the dairy sector involves currency parity. Since the second half of 2014, the exchange rate of the Euro against the American Dollar depreciated by around 20 percent, thereby creating a lever for exporting dairy products from member states of the Euro zone. While this tendency should change in the middle term, with the Euro returning to the exchange rate from the second half of the 1990s, this could hinder the price competitiveness of European countries over third countries, accentuating the overproduction crisis. This is a fairly realistic assumption, insofar as the parity of the Euro has recovered since March 2015 in a context of potential currency war.

Finally, this overproduction led to a significant decrease in both milk prices and farmers' incomes over more than two years, which can be seen in the Milk Market Observatory of the European Commission itself (Figure 5). 


\section{Absence of efficient tools to solve the crisis}

Beginning in 2009, several EU initiatives aimed to meet a new context of market deregulation with new price volatility and the historical dismantling of supervised relations between producers and processing firms. European and national laws were passed, aiming at reinforcing the position of milk producers-against downstream companies-followed by a new European regulation for organizing agricultural markets in 2013.

It is interesting to consider the new intervention tools offered by European laws, and whether they can, or cannot, solve a crisis like that currently experienced by the dairy sector. Of note is the absence of the notion of crisis in European legislation; these laws prefer to refer to the notion of market "imbalance." As such, the EU lets production prices and volumes vary with the market. The intervention tools support producers with direct aid per hectare-which is not supposed to influence farmers' decisions related to production-and manage, ex-post, price drops by possibly compensating producers according to the now-crucial principle of decoupling any aid given per hectare of agricultural land from any link to production. Finally, they rely essentially on private co-ordination. These laws are different from those aiming to stabilize the market ex ante, which were built up and applied for 30 years within the framework of the CAP, and then dismantled progressively.

Among the remaining tools, let us first mention tools for public storage. In the past, dairy producers were guaranteed minimum prices. When European rates reached these minimum prices, production was bought back and stored by the EU, then most often exported thanks to export aid. Milk quotas made it possible to stabilize European prices. These guaranteed prices, described today as "safety nets," were progressively decreased to a very low level-since 2009, $1698 € / \mathrm{t}$ for skimmed milk powder and $2218 € / \mathrm{t}$ for butter-no longer making it possible to stabilize prices paid to producers. This was accompanied by changes to the provisions for storage that restricted opening periods and annual ceilings. The public storage law was activated for only a few months in 2009, and once again in 2015, both times for very limited quantities only. Moreover, the intervention price, equivalent to around 220 $€ / \mathrm{t}$ paid to producers for milk, turned out to be incompatible with the long-term maintenance of most dairy farms.

This resulted in recurring requests for the intervention prices to be adjusted. These requests were supported by several European economic actors and countries, including France. Nevertheless, such requests were met with important institutional brakes, one being the hostility of the other member states, including Ireland and Germany, and raised the issue of conditions for selling stocks in the absence of mechanisms for controlling production volumes, as well as export aid.

Private storage aid by companies can be activated only in response to economic difficulties encountered in the sector, for butter, cheese, and powdered skimmed milk. The European Commission has activated this aid since 2014. Questions about its efficiency remain, nonetheless, because it was obviously unable to curb the decline in the price of dairy products. Two criticisms about this can be highlighted:

- Aid paid to private storage is being captured by private transformers, with no transmission to the price paid to producers; and 
- Speculative behaviours from these transformers, with reverse effects to those expected on prices. $^{20}$

The crisis reserve is another tool for managing imbalances expected by the 2013 new European laws. The crisis reserve can be activated "when circumstances do not correspond to the normal evolution of the market." This reserve reached 433 million Euros in 2015, with a yearly budget that seems clearly insufficient to cover all agricultural productions. Aid to mutual funds ${ }^{21}$ could constitute a new means of ensuring dairy producers' incomes. However, only three locations-Hungary, Italy, and the Spanish region of Castilla y Leon-have adopted this measure for the time being, with different conditions. Beyond the classic criticisms addressed to this type of measure-for example, systemic risk, in particular, causing subscribers as a whole to be affected at the same time and to dry up the fund in question-several other limits are linked to this measure and depend on meeting WTO requirements exactly:

- Losses of at least 30 percent of the farmer's income are required before the fund can be activated-with the fund covering only 70 percent of losses; and

- Public support concerns only administrative costs and paid compensations, and not the initial capital.

The EU Milk Market Observatory, operational since 2014, makes data and analyses on dairy markets available. It constitutes a true advance in dairy market transparency, even if the absence or lack of precision in some data is unfortunate, particularly in terms of the margins of producers (on an intra-European scale) and other economic actors in the industry, all available stocks, and mixed products. However, in no way does it constitute an intervention tool for markets, or even a crisis-warning tool.

Other crisis-management measures appeared in European laws as well. As such, it was possible to extend, in case of crisis, the period of public and private storage, and to pay emergency aid to European livestock farmers. These "cosmetic" measures were used, unsuccessfully, in 2015 by the European Commission; in fact, the dairy crisis worsened.

Faced with increasing difficulties and a worsening crisis, the tools made available recently on the European scale appear incapable of solving a crisis of this nature. Thoughts of private planning or even production volume control have resurfaced in a much-differentiated manner, depending on the countries. But these tools remain provisional, as was the case for Friesland Campina, Holland's main dairy cooperative. It granted a price increase of 20 cents per litre for almost two months at the beginning of 2016 to producers who could control their volumes. These tools can also be very indirect, as is the case for Holland again, which is putting an upper limit on the number of cows per hectare for environmental reasons.

Where there was a risk that these measures would not be efficient, an amendment to the single Common Market Organisation (CMO) was introduced to the European Parliament in 2013. It proposes that, in case of crisis, a bonus should be paid to livestock farmers who lower production over a given period, while a surcharge should be levied on those who increase it beyond a specific threshold. The amendment was 
rejected by countries such as Germany, which at the time opposed any supply regulation for the dairy sector. More recently, the European Parliament adopted a resolution that is very critical of dairy market deregulation, and advocates a return to the compulsory management of production volumes in case of crisis. ${ }^{22}$ Finally in 2016, faced with a long-lasting decrease in milk price, the member states proposed financial support to European producers who undertook to reduce their production. Nevertheless, the total credit allocated to this measure remained inadequate and was used up in the space of a few months. This measure for the management of production volumes on a European scale did not have the support of a political majority at the European level, so it stopped in early 2017.

\section{Economic theories and dairy crisis: three perspectives}

Until very recently, the European Commission denied the crisis, a position that calls for critical analysis, insofar as it is indissociable from a surprisingly resilient liberal vision of how the economy functions. It is necessary to turn to economic theories to bring to light the errors of anticipation of the European Commission and several member states, and show how such errors emanate from an unsuitable, or even erroneous, conception of the competitive market economy. It is precisely when there is a crisis that schools of thought need to be (re)examined. ${ }^{23}$ This article focuses on three particular theories: Jean-Baptiste Say's law of markets, Karl Marx's Capital, and John Maurice Clark's principle of acceleration.

\section{Dairy crisis and the "law of markets"}

The decision to abolish milk quotas relied from the very beginning on the assumption that the excess milk production caused by the abolition of quotas was to be absorbed by a fast-expanding global demand. Indeed, as soon as consumers experience a sufficiently high buying power, they will absorb the proposed productions.

This vision of the way competitive market economies work has a name: the "law of markets," as spelled out by Jean-Baptiste Say in the nineteenth century. It reflects the idea that any company producing goods also creates a buying power able to pay for other goods of a value equal to the former. Say indicates the following:

It is worthwhile to note that a product is no sooner created than, from that instant, it affords a market for other products to the full extent of its own value. When the producer has put the finishing hand to his product, he is most anxious to sell it immediately, lest its value should diminish in his hands. Nor is he less anxious to dispose of the money he may get for it; for the value of money is also perishable. But the only way to get rid of money is in the purchase of some product or other. Thus the mere circumstance of creation of one product immediately opens a vent for other products. ${ }^{24}$

What can we learn from this excerpt that basically means that "any supply creates its own demand and brings it to its own level," and that the value produced is equal to that of incomes distributed? Say thus denies any possibility of crisis underlain by overproduction. He agrees with James Mill, who, in 1808, asserted that we must be 
totally assured that the annual product of a nation will always be fully consumed. ${ }^{25}$ The case of the dairy sector bears witness to the longevity of this law.

Say's law usually applies to macroeconomics, but we propose to use it to interpret the milk crisis from a sectoral perspective. Say is one of those classical economists for whom production necessarily leads to purchase. Just like Say, Stuart Mill considered that doubling the volume of goods produced would also double the purchasing power, which will facilitate the absorption of the increase in production on all markets. These authors build this supply-demand concordance on a very restrictive concept of market transactions, where the means of payment of goods are the goods themselves. While such an approach to the way markets operate might not be shared by the economic mainstream's neoclassical theory, it remains one of the guiding threads of neoclassical theory, according to John Maynard Keynes. ${ }^{26}$

The European Commission and the member states most relieved by the abolition of milk quotas made the same mistake as Say by neglecting the reality of the market's inadequacy that emanates from a slowdown in economic growth that compelled economic agents to consume less and save more. The withdrawal of money from the economic circuits leads to an overproduction process, invalidating the "law of markets." This is what today's heterodox economists advance, as does Jean de Sismondi, for whom the act of consuming does not necessarily overlap that of producing, an approach that experienced a renewal of interest with Keynes and his principle of "effective demand."

Sismondi points out that the capitalist system is unable to avoid the serious economic crises that occur at regular intervals because this system does not produce values in use but in exchangeable goods, without knowing whether they are useful or not. Moreover, the consumers of a given country or area can experience a drop in their buying power. Consequently, the quest for new markets can be only provisional: markets will contract in turn under the effects of a slowdown of the growth of the demand. ${ }^{27}$

Sismondi's rejection of Say's law relies on a reasoning that, today, can shed light on the dairy crisis. Indeed, Sismondi explains that, in a decentralized economy, producers' decisions rely on anticipations prior to the actual state of the market. Producers evolve in a radical state of uncertainty, as far as the capacity of the market to absorb their supply is concerned. Their wish to utilize their production potential fully without knowing the market leads them to overproduce. Is not this, on a larger scale, the error of anticipation made by milk producers in Northern Europe and by the European Commission?

The actual functioning of a competitive market economy is characterized by a lack of ex-ante co-ordination of investment decisions made by producers. The latter then compete to capture a maximum of market shares; actors in the main production areas make the same bet. The determined increase in milk quotas by more than one percent during the 2006-to-2015 period was a strong incentive for producers to incur productive investments and increase production. The only possible regulation by the market is that which leads to eliminating producers that are least resilient to the drop in price caused by the overproduction of supply.

\section{Dairy crisis and production anarchy: return to Marx}

Several theorists contested the heuristic value of the "law of markets," among them Thomas Malthus, Jean de Sismondi, and, in particular, Karl Marx. Their vision of the 
market offers a possible avenue for interpreting the crisis in which the dairy sector finds itself today. Marx's message in relation to the sector or general crises in capitalism resonates with the current period.

Embracing forecasts of increased demand for dairy products worldwide, European actors in favour of eliminating quotas thought that expanding the demand would lead to remunerative market prices and, in fine, to prospects of increased returns on past productive investments. Capital accumulation in agriculture could then develop, causing the global market to open up. Nonetheless, the production dynamic takes place according to an anarchic logic, due to both the national character of production and the producers' lack of co-ordination. Each milk producer and each dairy transformation industrialist intends to capitalize on the announced expansion of the demand worldwide, where the increase in the volumes of milk and dairy products offered on the market will be self-maintaining.

International institutions have had a real influence on the decision of milk producers to produce more for markets seen as expanding. They have encouraged overproduction by delivering a message that global demand for dairy products is on an upward trend, driven by emerging nations. The OECD and the FAO are perfect examples of this attitude, reflecting the belief in the global market's ability to absorb the increased production of milk and dairy products. These international institutions carry the liberal message and its dissemination on a global scale, thus justifying criticisms of agricultural policies. By loosening the constraint of agricultural policy such as the CAP, international institutions such as the OECD maintain the illusion of a perfectly competitive market. However, Marx demonstrated how the competitive game pushes producers to an escalation of production.

The dairy sector evolves within a business economy in which the social product is formed through the confrontation of private autonomous works. In addition, the resulting fierceness of the competitive process comes up against the inadequacy of demand, which, as seen previously, gradually shrinks markets and returns on investments. The crisis has been triggered in the dairy sector, with the risk of spreading to the entire economy: the animal-feeding sector losing markets due to cost savings sought by livestock farmers; the banking system unable to collect debts on credits initially granted; etc. ${ }^{28}$ As such, the end of the expansion of demand for dairy products worldwide has, through the drop in prices, made livestock farmers from New Zealand vulnerable. The depreciation of their profitability is pushing the banking sector to restrict the credits granted, thereby making dairy farms even more vulnerable. The deterioration of the value of dairy farms is arousing interest from international investors, following the example of China that, in 2015 and 2016, took over some of them. ${ }^{29}$

\section{Dairy crisis and production capacity adjustment difficulties}

Characterizing an agricultural crisis requires us to look into the adjustment process of production capacities, to the dynamic of markets on which demand is able to absorb volumes. On this point, we can refer to analyses produced by the French economist Albert Aftalion at the beginning of the twentieth century. When an expansion period occurs, it is followed by an increase in production capacities caused by market expectations. In the case of the dairy sector, the prospect of an increase in 


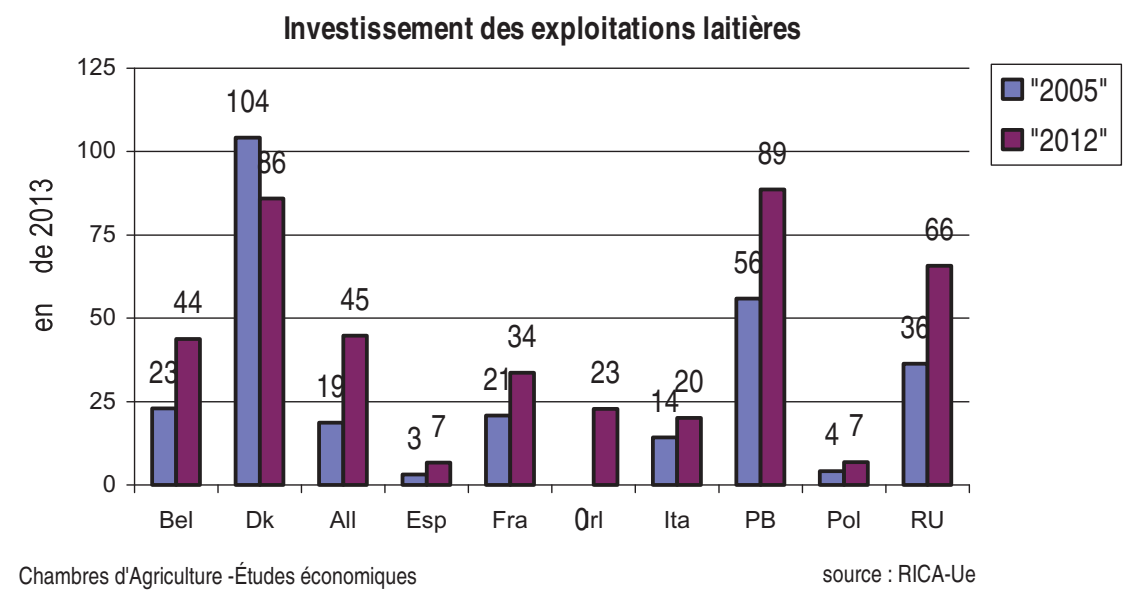

Figure 6. Bullish Trend of Productive Investment in Dairy Farms.

global demand had led the EU to abolish quotas. Due to time gaps between investments and the growth of production capacities on the one hand, and the true state of the demand on the other, an overcapacity process takes place. According to Aftalion, this phase difference is what leads to a crisis. It is said that the supply is not in proportion to the demand. ${ }^{30}$

This approach to the possibility of a crisis in a sector such as agriculture, and the dairy industry, in particular, is an extension of the famous principle of acceleration in the work of John Maurice Clark. ${ }^{31}$ According to his acceleration principle, a productive investment-the demand for capital goods-is a function of the demand for finished products. In other words, the demand for capital goods derives, or is induced from, the final demand. As soon as the demand for finished products increases or decreases, it has a ripple effect-bullish or bearish-on investments and production. In the case of the dairy sector, the current crisis is characterized by overproduction resulting from an overinvestment dynamic that began in the middle of the 2000s, linked to an anticipated final demand far greater than what it is today.

The dairy crisis, which has lasted for more than two years, cannot be dissociated from the productive investment dynamic and from the anticipations that are its main determining factor. As such, livestock farmers were encouraged to adjust their production volumes according to this bullish global demand perspective, in a context of the firmness of dairy product prices. A virtuous circle could then become established: increased investment, increased production, remunerative prices with a sufficiently dynamic global demand, and perspectives of profitability. Many investments in dairy farms were made in previous years, in order to prepare for an increase in supply, except in Denmark (Figure 6). As soon as global demand turns around during the next phase, and European supply is no longer constrained by the quota system, the "tragedy of investment" - in the words of Michael Kalecki in 1935-settles in again. It follows that the dairy crisis is more likely explained as resulting from factors that are endogenous to the sector rather than exogenous shocks.

The relatively rigid productive capacity (cf. $\$ 1$ ) can continue to increase while demand is already in a phase of contraction. This is a distinctive feature of the agricultural market 
and one that actors-who are the most directly influenced by, and convinced of, the efficiency of the regulation by the market-obviously find hard to accept.

\section{Conclusions}

The factors worsening the dairy crisis seem to be as follows: macroeconomic evolutions characterized by radical uncertainty, and crisis-solving political tools that, on the European scale, are at best inefficient and at worst absent. The crisis-solving instruments contained in the CAP, therefore, must be re-examined.

Considering the differences of approach within the EU, we know that this reexamination will not lead to the reconciliation of viewpoints, where the existence of a political and economic demarcation line bringing into conflict member countries, such as France, and member states of the North, such as Ireland and Holland, is particularly tight, especially as regards the management of production volumes. The question is to know whether we need to embark on a policy aiming at protecting dairy farming or, $a$ contrario, whether we need to admit that the ongoing reorganization of dairy production and, as a result, the dairy industry must be brought to completion.

In any case, the general tendency towards increasing production remains, despite the drop in price. Ireland constitutes a very good example of this strategy. For this member state, the current crisis is not meant to last, and producers must prepare to meet the demand by adopting a supply behaviour adapted to the announced increase of milk demand. ${ }^{32}$ This strategy is also adopted and supported by member states, such as Germany and the Netherlands, as well as by some lobbies, in particular those representing big milk industries. It seems that, at the end of 2016, international and European prices have stopped dropping and are even beginning to increase slightly. But this slight improvement can only be precarious because no efficient measure for stabilizing markets and solving overproduction crises has been decided.

Finally, this article wishes to show the decisive importance of the history of economic thought and how it can help us to understand and interpret a market crisis like the one that has affected the dairy sector since 2014. Indeed, the economic reasoning held by the European Commission and its economists shows the extent to which they consider history irrelevant, or at least how little they know of it. By considering the crisis in the dairy sector as a fully-fledged economic production, we invite the reader to develop an active relation to the history of economic thought. ${ }^{33}$

\section{Notes}

1. Trouvé et al., Étude Sur les Mesures Contre les Déséquilibres de Marché.

2. We rely on a study conducted in 2015-2016 (Trouvé et al., 2016) and financed by the Ministry of Agriculture, Agro-Food and Forestry. Within this framework, around 80 targetted interviews have been conducted with administrative and political representatives, representatives of the farming profession and the dairy industry. They were done in Belgium, Germany, Holland, Ireland, and France. These interviews aimed at understanding how the milk sector works and the position of each institutional stakeholder on the evolution of milk policies. 
3. Sumner, "Effects of Government Programs to Raise Milk Prices."

4. Mazier et al., Quand Les Crises Durent; Boyer, Economie Politique Des Capitalismes.

5. Boussard et al., Libéraliser L'agriculture Mondiale?

6. Hathaway, Market Government and Agriculture, 1968.

7. Allaire and Dervillé, "Quelles perspectives pour les filières laitières de montagne."

8. Courleux and Dedieu, "Les Enjeux de la Régulation du Secteur Laitier."

9. OECD-FAO, Perspectives Agricoles de l'OCDE et de la FAO, 2014-2021, Perspectives Agricoles de l'OCDE et de la FAO, 2014-2023.

10. Chaumet and Pouch, La Chine au Risque de la Dépendance Alimentaire.

11. Jongeneel and Van Berkum, "What Will Happen After the EU Milk Quota System Expires in 2015?"

12. Data from the EU Milk Market Observatory.

13. IMF, Perspectives De L'économie Mondiale.

14. This lesser dynamic of world economics affects almost all basic products, starting with oil. In this instance, we know that the price decrease has seriously affected producing countries, and Venezuela in particular, which is experiencing a serious and concerning structural economic, financial, and political crisis (de Charentenay, 2015). In the case of Venezuela, "the Dutch disease" or "the raw materials curse" has been unfurling.

15. Aglietta and Coudert, "Les cycles de l'endettement."

16. Chaponnière and Lautier, Les Economies Emergentes D'asie.

17. European Commission, 2014.

18. CNIEL, 2015.

19. Sources of data: USDA, European Commission, OECD, ATLA.

20. Gérard et al., Stabilisation des Prix des Céréales.

21. Mutual funds are funds shared by the farmers of a region; they benefit from the annual contributions of each farmer and pay out in case of crisis.

22. European Parliament, 2015.

23. de Gaudemar, "Faire de l'histoire"; Rosier, Les Théories des Crises Economiques; Campagnolo, Critique de l'économie Politique Classique.

24. Say, Traité D'économie Politique, 138-9.

25. Denis, La Loi de Say Sera-T-Elle Enfin Rejetée?

26. Keynes, The General Theory of Employment, Interest and Money.

27. Sismondi, Nouveaux Principes D'économie Politique.

28. Marx, Le Capital; Mattick, Marx et Keynes; Aglietta, Régulation et Crises du Capitalisme.

29. Chaumet and Pouch, La Chine Au Risque.

30. Aftalion, Les Crises Périodiques.

31. Clark, "Business Acceleration and The Law Of Demand"; Duharcourt, La Fonction d'investissement.

32. Food Wise Programme, 2025.

33. de Gaudemar, "Faire de l'histoire."

\section{Disclosure statement}

No potential conflict of interest was reported by the authors.

\section{About the authors}

Thierry Pouch is Head of Economic Studies at the Permanent Assemblies of Chambers of Agriculture (APCA) in Paris, France, and teaches at the Laboratoire Regards at the Université de Reims Champagne Ardenne, in Reims, France.

Aurélie Trouvé teaches at AgroParisTech in Paris, France. 


\section{Bibliography}

Aftalion, Albert. Les Crises Périodiques de Surproduction. Paris: M. Rivière, 1913.

Aglietta, Michel. Régulation et Crises du Capitalisme: L'expérience des Etats-Unis. Paris: Calmann-Lévy, 1976.

Aglietta, Michel, and Virginie Coudert. "Les cycles de l'endettement: le dollar et l'économie mondiale," La Lettre du CEPII, no. 359 (2015): 1-4.

Allaire, Gilles, and Marie Derville. "Quelles perspectives pour les filières laitières de montagne après la suppression des quotas laitiers? Une approche en termes de régime de concurrence," INRA-Productions animales 27, no. 1 (2014): 17-30.

Boussard, Jean-Marc. Françoise Gerard, and Marie Gabrielle Piketty. Libéraliser L'agriculture Mondiale?: Théories, Modèles Et Réalités. Versailles: Cirad, 2005: 135.

Boyer, Robert. Economie Politique Des Capitalismes. Editions La Découverte, Coll. "RepèresManuels."

Campagnolo, Gilles. Critique De L'économie Politique Classique. Marx, Menger et L'ecole Historique Allemande, Editions Matériologiques, 2014. Coll. "E-Conomiques"

Chaponniere, Jean-Raphael, and Marc Lautier. Les Economies Emergentes D'asie, Entre Etats Et Marché. Armand Colin, 2014. Coll. "U."

Chaumet, Jean-Marc, and Thierry Pouch. La Chine Au Risque de la Dépendance Alimentaire. Rennes: Presses Universitaires De Rennes, 2017. Coll. "Économie Et Société."

Clark, John Maurice. "Business Acceleration and the Law of Demand: A Technical Factor in Economic Cycles," Journal Of Political Economy 25, (1917): 17-35.

Cniel. L'économie Laitière En Chiffres. Paris, 2015.

Commission Europeenne. Prospects For Eu Agricultural Markets And Income 2014-2024, Bruxels: Commission Europeenne (2014).

Courleux Frederic, and Dedieu Marie-Sophie. "Les Enjeux de la Régulation du Secteur Laitier," Analyse, Prospective Et Evaluation, Maaf, Centre d'études Prospectives, no. 11 (2009): 1-4.

de Charentenay, Pierre. "Le Venezuela: Un Pays Affaibli Et Divisé." Etudes, Revue De Culture Contemporaine, no. 7-8 (2015): 7-19.

de Gaudemar, Jean-Paul. "Faire de l'histoire de la Pensée Economique. Questions Pour un Débat." Revue Economique, no. 4 (1978): 655-87.

de Sismonde, Sismondi Jean Charles Léonard. Nouveaux Principes D'économie Politique, Ou de la Richesse Dans Ses Rapports Avec La Population. Paris: Calmann-Lévy, 1971.

Denis, Henri. La Loi de Say Sera-T-Elle Enfin Rejetée? Editions Economica, 1999.

Duharcourt, Pierre. La Fonction d'investissement. Paris: Sirey, 1970.

Ezekiel, Mordecai. "The Cobweb Theorem," Quarterly Journal of Economics 52, no. 2 (1938): 255-80.

FMI. Perspectives De L'économie Mondiale. Washington: Fonds Monétaire International, 2015.

Gerard, Françoise, Marie Gabrielle Piketty, and Jean-Marc Boussard. Stabilisation des Prix Des Céréales: Avantages Et Coûts Du Stockage Public, Centre d'études Prospectives, Ministère De L'agriculture, 2013.

Hathaway, Dale E. Government and Agriculture: Economic Policy in a Democratic Society. New York: MacMillan Company, 1968.

Jongeneel Roel, and Siemen van Berkum. What Will Happen After the EU Milk Quota System Expires in 2015?: Assessment of the Dutch Dairy Sector. Wageningen, Lei, University And Research Center, 2015: 1-27.

Kalecki, Michal. "A Macrodynamic Theory of the Business Cycle." Econometrica 3, no. 3 (1935): 327-44.

Keynes, John Maynard. Treatise on Money. London: MacMillan, 1930.

Keynes, John Maynard. The General Theory of Employment, Interest and Money. Palgrave: MacMillan, 1936.

OCDE-FAO. Perspectives Agricoles De L'ocde Et De La Fao, 2014-2021. Paris: OCDE-FAO, 2012. 
OCDE-FAO. Perspectives Agricoles De L'ocde Et De La Fao, 2014-2023. Paris: OCDE-FAO, 2014.

Marx, Karl. Le Capital: Critique De L'économie Politique, Livre I. Editions Sociales, 1978 Pour La Traduction Française, 1867.

Mattick, Paul. Marx et Keynes: Les Limites de l'économie Mixte. Gallimard Pour La Traduction Française, 1972.

Mazier, Jacques, Maurice Basle, and Jean-Franc, ois Vidal. Quand les Crises Durent. Paris: Economica, 1984.

Parlement Européen. Résolution Du 7 Juillet 2015 Sur L'avenir Du Secteur Laitier Européen: Bilan de la Mise en OEuvre du 'Paquet Lait.' Rapport, Strasbourg, 2015.

Rosier, M. Les Théories Des Crises Economiques. Paris: La Découverte, Coll. "Repères.” 1987.

Say, Jean-Baptiste. Traité D’économie Politique. Paris: Calmann-Lévy, 1972.

Sumner, D.A. "Effects of Government Programs to Raise Milk Prices: Academic Economists and Public Policy." Agribusiness 21, no. 4 (2005): 451-586.

Trouvé, Aurélie, Marie Derville, Daniel-Mercier-Gouin, Thierry Pouch, Jean-Christophe Kroll, Olivier Rat-Aspert, Xavier Briot, and Pierre Lambaré. Étude sur les Mesures Contre les Déséquilibres de Marché: Quelles Perspectives Pour L'après Quotas Dans Le Secteur Laitier Européen? Paris: Rapport au Ministère français de l'agriculture, MAAF-SSP, Centre d'Études Prospectives, 2014/027, 2016. 